Arab World English Journal (AWEJ) Volume 12. Number3 September 2021 DOI: https://dx.doi.org/10.24093/awej/vol12no3.21

\title{
Teacher Electronic Written Corrective Feedback, Trends and Future Directions
}

\author{
Omar Abdullah Altamimi \\ center for Instructional Technology and Multimedia \\ Universiti Sains Malaysia. Malaysia \\ Corresponding Author: omaraltamimi@ @student.usm.my \\ Mona Masood \\ center for Instructional Technology and Multimedia \\ Universiti Sains Malaysia. Malaysia
}

Received: 7/21/2021

Accepted: 8/30/2021

Published: $9 / 24 / 21$

\section{Abstract:}

The past two decades witnessed increased attention in the role of Written Corrective Feedback (WCF) in improving the English as a second language(ESL) students' written linguistic accuracy. Several methods were suggested, including the use of the electronic means of providing corrective feedback. The electronic methods proved to be effective despite the limited numbers and contexts. However, the extent of these studies is still unknown. Furthermore, no comprehensive review of the studies had been conducted to date. This systematic literature review will identify and classify the research on providing ESL teachers with Electronic Written Corrective Feedback (EWCF). A survey of several experimental and analytical studies that focused on testing the effect of different methods of EWCF on ESL students was conducted, covering the period between 2006 and 2020. Two major groups of studies emerged from this research, and several gaps were identified. The research concluded with several recommendations regarding the potential tracks for future research on EWCF. The current research will serve as a guideline for ESL writing practitioners and researchers on future teacher corrective feedback in second language writing.

Keywords: electronic corrective feedback, ESL/EFL learners, grammatical errors, systematic literature review, written errors

Cite as: Altamimi, O. A., \& Masood, M. (2021). Teacher Electronic Written Corrective Feedback, Trends and Future Directions . Arab World English Journal, 12 (3) 308-322. DOI: https://dx.doi.org/10.24093/awej/vol12no3.21 


\section{Introduction}

The arrival of new technologies, such as personal computers and internet technologies, has opened new possibilities for second language teaching and research. Therefore, language teaching and learning started to pay attention to computers and internet applications as a means of communication between teachers and students and between the students themselves (Razagifard \& Razzaghifard, 2011). Several reasons led to the adoption of technology in the field of ESL learning and teaching. One reason includes the affordability and accessibility of the technology that facilitated its use inside and outside the classroom (DeBell, 2003), as well as their positive effects in improving the students' linguistic accuracy (Bataineh, 2014) and the positive attitudes that the students reveal when using these technologies (He, 2016; Lv, 2018). As a result, teachers and students depend more on exchanging assignments and Feedback electronically (Ene \& Upton, 2014). Furthermore, using technology tends to be favoured by both learners and instructors (Hyland, 2010). In addition, using technology in the classroom leads to increased motivation among students (Warschauer, 1996).

Second language writing specialists also started to get attracted by the new technologies' potentials (Ene \& Upton, 2018), mainly using them to provide corrective feedback to their students' writings. Providing written corrective feedback is considered an essential part of L2 Writing instruction (Hyland \& Hyland, 2006). Teachers bear a greater responsibility to help their students improve their written assignments and reduce their grammatical errors because they know that such errors will negatively affect their students in their future pursuits (Hyland \& Hyland, 2006). As a result, they spare no effort to find the best tools and practices to assist their students.

A potential solution comes from utilizing technological advancement in the ESL writing teaching process. Providing Electronic WCF has an obvious advantage over the traditional method (pen and paper) to rectify the students' grammatical errors (Xu, Banerjee, Ramirez, Zhu, \& Wijekumar, 2019). Written computer-mediated communications have the potential of helping learners to acquire complex forms (Kim, 2014; Sauro, 2009) and deepen the learners' commitment (Maas, 2017). Using technology in writing leads to decreased students' anxiety and increased motivation (Pellettieri, 2000). Because of these factors, the need arises to expand the Corrective Feedback (CF) studies to include the electronic environments (Ene \& Upton, 2018). The potential benefits of technology led to a steady increase in electronic corrective feedback studies (Hosseini, 2012).

Even though the new technologies may hold a promise for second language writing, more research is still needed. Few studies were conducted on different electronic corrective feedback types (Rassaei, 2019; Ribeiro, 2018). Most of the studies of Electronic CF investigated two methods of delivering the written feedback to the students. The methods are 1- repeating the same utterance minus the error or2- giving a metalinguistic explanation of the error made (Akbar, 2017; Hosseini, 2012). In general, the studies that investigated the effectiveness of Electronic Corrective Feedback ECF are scarce (Ene \& Upton, 2014, 2018), even though researchers have a consensus on its potentials in improving the students' written accuracy (Ene \& Upton, 2014). 


\section{The Current Study}

This report summarizes the studies that investigated the impact of EWCF on ESL/EFL students' written grammatical accuracy. To have a clearer picture of the current status and development in the field, a need to conduct systematic literature review of studies that investigated the use of Electronic corrective feedback and its effectiveness in improving ESL students' written grammatical errors. The review will assist in surveying what studies were conducted to identify what methods and tools proved helpful. It will also pinpoint the possible

directions for future studies. Therefore, the following inclusion/exclusion criteria were devised:

1- The study can be experimental (it involves testing a method of electronic feedback against one or more methods) or an analytical study (a study that analyses the teachers' electronic corrective feedback in its natural settings). Studies that investigated the students' attitudes only were excluded.

2- They must be studies that only involve Electronic Written Corrective feedback by the teachers. Studies That involved the provision of peer feedback were excluded. It also means that studies that compared both traditional and electronic feedback were also excluded.

3- The Feedback given to the students should be provided electronically. Studies that investigated the traditional feedback method through pen and paper are excluded. Studies that examined the role of Automated Essay Scoring technologies were also excluded from the study

4- The studies included must focus on written grammatical accuracy. Studies that focused on other aspects, such as phonological, semantic, or other aspects, were excluded. Also, studies that focused that grammatical knowledge presented through oral exams were excluded.

5- The studies must focus on learners who study English as a second or foreign language. Studies of other languages rather than English were excluded.

6- The studies must be published in English-language journals.

\section{Search Terminology}

Because different researchers can use slightly different terminology to report their research findings, they decided to use several search words and phrases. The phrases used in this Systematic literature review (SLR) are as the following:

1- Electronic Feedback

1- Electronic corrective Feedback

2- Electronic written Feedback

3- Electronic grammatical Feedback

4- Computer-mediated corrective Feedback

5- Computer-based corrective Feedback

\section{Methodology}

After deciding on the search terminology and the exclusion/ inclusion criteria, the research process has started by choosing the databases to be utilized. The study included three databases: 1-Ebscohost, 2- Scopus, and 3- Google Scholar. All the search phrases were applied to the three databases. The total hits of the first search in all the databases were 2594. The studies' titles and abstracts were initially examined against the inclusion/ exclusion criteria, and the duplicates were removed. The remaining 219 studies were examined extensively against the inclusion/ exclusion criteria leading to 28 studies as the final results. The studies cover the range from 2006 (when the first study was conducted) to 2020. 


\section{Results and Analysis}

This section presents the results from the finalized 28 studies used to draw preliminary conclusions regarding the use of EWCF. The selected studies were reviewed to identify the ESL Writing teachers' ECF trends and identify possible gaps that could help guide future research.

The 28 studies under examination can be classified into two main groups; The first group is the analytical studies. These studies were conducted in natural settings without any manipulation or intervention from the researcher. The total number of these studies is nine studies. Appendix A summarizes the main finding of these studies. The main points in appendix A are the purpose and results of the study, information about the participants (number of participants and their proficiency levels), the Electronic CF feedback given (is it synchronous or asynchronous? what type of feedback was provided? and what tool was used to provide the feedback?), and how the researcher collected the data. More detailed analysis of the salient features will be provided in the following subsections:

\section{Analytical Studies}

The first aspect that was analyzed in the nine studies was their purpose. Two main themes can be tracked as the following:

Investigating the effectiveness of EWCF.

Four of the nine studies focused on investigating the effectiveness of the electronic corrective feedback EWCF given to the students. Two of the studies investigated the effectiveness of EWCF when it is delivered asynchronously. The first was a case study (MartinBeltrán \& Chen, 2013) that involved three Writing teachers and six ESL students and tried to examine the learning stances during the online asynchronous activities. The second study (Ene \& Upton, 2014) investigated the relationship between three writing teachers' ECF practices and their effect on twelve ESL students when given asynchronously. Only one study examined synchronous EWCF (Kim, 2014). It was conducted on 28 intermediate ESL students and attempted to explain how synchronous writing activities may help draw learners' attention to their written grammatical errors. The last study targeted a larger group of advanced students $(\mathrm{n}=$ 64) and investigated the electronic feedback offered by teachers synchronously and asynchronously (Ene \& Upton, 2018).

\section{Investigating the type of EWCF.}

Six of the studies focused on the type of EWCF given to the students. The first study tried to analyze the feedback given by 18 pre-service ESL teachers regarding EWCF types. Two studies (Ene \& Upton, 2014; Lee, Vahabi, \& Bikowski, 2018) analyzed the types of EWCF given by University writing instructors. Two studies (Akbar, 2017; Natsuko Shintani, 2015) investigated the different ECF types when given synchronously and asynchronously. Only one case study compared the ECF when delivered synchronously against face-to-face interaction (Ribeiro, 2018).

\section{Level of Targeted Population}

There is a tendency to target students with good proficiency levels of English. Most of the studies $(\mathrm{n}=4)$ were conducted on intermediate ESL students (Guénette \& Lyster, 2013a; Kim, 2014; Ribeiro, 2018; Shintani, 2015). Two studies were conducted on higher intermediate ESL students (Akbar, 2017; Lee et al., 2018). The remaining three studies were conducted on students 
enrolled in English for Academic Purposes in their universities (Ene \& Upton, 2014, 2018; Martin-Beltrán \& Chen, 2013). However, none of the studies investigated students with low proficiency in English.

\section{Results of the Studies}

The results' analysis indicates that the salient forms of EWCF tend to be more direct and explicit. In the four studies that analyzed the types of EWCF, it was found that in three of them (Ene \& Upton, 2014, 2018; Kim, 2014), teachers provided ECF that is direct and explicit, with only one study that indicated that recast is used in synchronous CMC (Ene \& Upton, 2018). To conclude, feedback tends to be more effective when provided explicitly and directly and less effective when provided implicitly.

\section{Experimental Studies}

The second group of studies are experimental studies. The researchers conducted these studies to test several variables and their effect on the EWCF process. Appendix B summarizes the main points of the studies. Most of the aspects analyzed in appendix B are similar to appendix Aabout analytical studies. Namely, the purpose and results of the study, information about the participants (number of participants and their proficiency levels), the EWCF given (is it synchronous or asynchronous? what type of feedback, and what tool was used to provide the feedback), and how the researcher collected the data. In addition to that, information about the targeted language, the dependent and independent variables was added. The following subsections contain a detailed analysis of these studies:

\section{Proficiency Levels of Participants}

The participants' proficiency levels are relatively evenly distributed through the EWCF studies, as shown in table1 below. Most of the studies $(n=9)$ focused on students with a broad range of intermediate proficiency levels (Low Intermediate, Intermediate, and High Intermediate). It can be noticed that no studies focused exclusively on advanced students. On the other hand, two of the studies combined advanced students with students from lower proficiency levels.

Table1. Level of Students

\begin{tabular}{|l|l|l|}
\hline & Level of Students & Number of Studies \\
\hline 1 & Elementary & 4 \\
\hline 2 & Low Intermediate & 3 \\
\hline 3 & Intermediate & 3 \\
\hline 4 & High Intermediate. & 3 \\
\hline 5 & Elementary to Advanced & 2 \\
\hline 6 & High Intermediate to Advanced & 2 \\
\hline 7 & First-Year Composition & 2 \\
\hline
\end{tabular}




\section{Type of Electronic Corrective Feedback.}

Specific feedback methods are prominent in EWCF studies. Table 2 describes the frequency of feedback types investigated in the asynchronous, synchronous, and combination of both synchronous and asynchronous modes. The majority of studies were conducted when feedback was given asynchronously (11 studies). Most of them focused on comparing direct EWCF's effect against recasts $(n=3)$ or metalinguistic explanation $(n=2)$. The remaining six studies were distributed evenly among the other methods of EWCF. Six of the experimental studies investigated the effectiveness of providing ECF synchronously. The main focus of them was on examining the effectiveness of Recasts. Only two studies compared both modes. The majority of studies $(n=5)$ compared the effect of recast and metalinguistic feedback types.

Table 2. Type of EWCF

\begin{tabular}{|c|c|c|c|c|c|c|c|c|c|}
\hline & $\begin{array}{c}\text { Recast vs } \\
\text { Metalingui } \\
\text { stic }\end{array}$ & $\begin{array}{c}\text { Reca } \\
\text { st vs } \\
\text { Dire } \\
\text { ct }\end{array}$ & $\begin{array}{c}\text { Reca } \\
\text { st vs } \\
\text { Prom } \\
\text { pt }\end{array}$ & $\begin{array}{c}\text { Direct and } \\
\text { Metalingui } \\
\text { stic }\end{array}$ & $\begin{array}{c}\text { Direct } \\
\text { vs } \\
\text { indire } \\
\text { ct, }\end{array}$ & $\begin{array}{c}\text { Metalingui } \\
\text { stic vs } \\
\text { exemplar }\end{array}$ & $\begin{array}{c}\text { Direct, } \\
\text { indirect, } \\
\text { and } \\
\text { metaling } \\
\text { uistic }\end{array}$ & $\begin{array}{c}\text { Rec } \\
\text { ast }\end{array}$ & $\begin{array}{c}\text { Direc } \\
\text { t }\end{array}$ \\
\hline $\begin{array}{c}\text { Asynchron } \\
\text { ous }\end{array}$ & 1 & 3 & 1 & 2 & 1 & 1 & 1 & 0 & 1 \\
\hline $\begin{array}{c}\text { Synchrono } \\
\text { us }\end{array}$ & 4 & 0 & 0 & 0 & 0 & 0 & 0 & 2 & 0 \\
\hline $\begin{array}{c}\text { Synchrono } \\
\text { us and } \\
\text { Asynchron } \\
\text { ous }\end{array}$ & 0 & 0 & 0 & 0 & 0 & 0 & 0 & 0 & 2 \\
\hline Total & 5 & 3 & 1 & 2 & 1 & 1 & 1 & 2 \\
\hline
\end{tabular}

\section{Effectiveness of Electronic Corrective Feedback}

Investigating the different EWCF methods' effectiveness, synchronously and asynchronously, shows relatively similar results, as shown in Table3. For instance, Recasts seems to be the least effective method of feedback when compared against the other treatments in the asynchronous studies. On the other hand, giving direct ECF and giving metalinguistic explanations has a more evident advantage. The same conclusion can be drawn when comparing the ECF effectiveness when provided synchronously. In the four studies that compared recasts and metalinguistic explanations, the latter shows superiority compared to the former. The last category describes a comparison of providing direct feedback synchronously and asynchronously. There are two studies in this category; the first investigated using direct feedback synchronously and asynchronously. Results indicated that both groups outperformed the control group in the post-test, but the synchronous group was better than the asynchronous group in the delayed post-test. Table 3 summarizes the main findings of this section.

Table 3. Effectiveness of EWCF Methods

\begin{tabular}{|c|c|c|c|c|c|c|c|c|c|}
\hline & $\begin{array}{c}\text { Recast vs } \\
\text { Metalinguist } \\
\text { ic }\end{array}$ & $\begin{array}{c}\text { Reca } \\
\text { st vs } \\
\text { Direc } \\
\mathrm{t}\end{array}$ & $\begin{array}{c}\text { Recast } \\
\text { vs } \\
\text { Prompt }\end{array}$ & $\begin{array}{c}\text { Direct and } \\
\text { Metalinguisti } \\
\mathrm{c}\end{array}$ & $\begin{array}{c}\text { Direct } \\
\text { vs } \\
\text { indirect, }\end{array}$ & $\begin{array}{c}\text { Metaling } \\
\text { uistic vs } \\
\text { exemplar }\end{array}$ & $\begin{array}{c}\text { Direct, } \\
\text { indirect, } \\
\text { and } \\
\text { meta } \\
\text { linguisti } \\
\text { c }\end{array}$ & $\begin{array}{c}\text { Recas } \\
\mathrm{t}\end{array}$ & $\begin{array}{c}\text { Direc } \\
\mathrm{t}\end{array}$ \\
& & & & & & & \\
\hline
\end{tabular}


Arab World English Journal (AWEJ) Volume 12. Number 3. September 2021

Teacher Electronic Written Corrective Feedback

Altamimi \& Masood

\begin{tabular}{|c|c|c|c|c|c|c|c|c|c|}
\hline $\begin{array}{l}\text { Asyn } \\
\text { chron } \\
\text { ous }\end{array}$ & $\begin{array}{l}\text { Recast }+ \text {, } \\
\text { Metalinguist } \\
\quad \text { ic - }\end{array}$ & $\begin{array}{c}\text { Reca } \\
\text { st - } \\
- \\
\text { Direc } \\
\mathrm{t}++ \\
+ \\
\end{array}$ & $\begin{array}{l}\text { Recast } \\
- \\
\text { Prompt } \\
\quad+\end{array}$ & $\begin{array}{c}\text { Direct - + } \\
\text { Metalinguisti } \\
\mathrm{c}++\end{array}$ & $*$ & $\begin{array}{c}\text { Metaling } \\
\text { uistic }+ \\
\text { Exemplar } \\
+\end{array}$ & Direct + & 0 & 0 \\
\hline $\begin{array}{l}\text { Sync } \\
\text { hrono } \\
\text { us }\end{array}$ & $\begin{array}{l}\text { Recast - - - } \\
\text { Metalinguist } \\
\text { ic - - ++ }\end{array}$ & 0 & 0 & 0 & 0 & 0 & & $* *$ & 0 \\
\hline $\begin{array}{l}\text { Sync } \\
\text { hrono } \\
\text { us } \\
\text { and } \\
\text { Asyn } \\
\text { chron } \\
\text { ous }\end{array}$ & 0 & 0 & 0 & 0 & 0 & 0 & 0 & 0 & $* * *$ \\
\hline \multicolumn{2}{|c|}{$\begin{array}{l}* \text { The study used a } \\
\text { combination of direct } \\
\text { and indirect feedback }\end{array}$} & \multicolumn{3}{|c|}{$\begin{array}{l}* * \text { Both studies were used only } \\
\text { to validate the application of the } \\
\text { eye-tracking technique as a } \\
\text { good measurement tool }\end{array}$} & \multicolumn{5}{|c|}{$\begin{array}{l}\text { *** There are two studies in this category; the } \\
\text { first investigated using direct feedback } \\
\text { synchronously and asynchronously. Results } \\
\text { indicated that both groups outperformed the } \\
\text { control group in the immediate test, but the } \\
\text { synchronous group was better than the } \\
\text { asynchronous group in the delayed post-test }\end{array}$} \\
\hline
\end{tabular}

\section{Study Methodology}

Table 4 shows the distribution of the methodology of studies of EWCF. Most of the asynchronous studies $(n=7)$ followed the pre-test, treatment, post-test methodology. Three of them added a delayed post-test to their methodologies. Only one study included the use of an eye tracker and a simulated recall. Most synchronous studies followed either the pre-test, treatment, post-test methodology (two studies) or delayed post-test treatment (two studies). Only one study included the use of an eye tracker in their investigation.

Table 4. Research Method of ECF Studies

\begin{tabular}{|c|c|c|c|c|c|}
\hline & $\begin{array}{c}\text { Pretest, } \\
\text { Treatment, } \\
\text { Posttest } \\
\text { Treatment, } \\
\text { Posttest, } \\
\text { Delayed } \\
\text { Posttest }\end{array}$ & $\begin{array}{c}\text { Pre-test, } \\
\text { treatment, } \\
\text { post-test, and } \\
\text { delayed post- } \\
\text { test. And Eye } \\
\text { tracker }\end{array}$ & $\begin{array}{c}\text { Pre-test, } \\
\text { treatment, post- } \\
\text { test, and } \\
\text { delayed post- } \\
\text { test, eye tracker } \\
\text { and Stimulated } \\
\text { recall }\end{array}$ & $\begin{array}{c}\text { Treatment and } \\
\text { Posttest } \\
\text { through eye } \\
\text { tracker }\end{array}$ \\
\hline Asynchronous & 7 & 3 & 0 & 1 & 0 \\
\hline Synchronous & 2 & 2 & 1 & 0 & 1 \\
\hline $\begin{array}{c}\text { Synchronous } \\
\text { and }\end{array}$ & 1 & 1 & 0 & 0 & 0 \\
Asynchronous & 10 & 6 & 1 & 1 & 1 \\
\hline Total & & & 0 & 0 \\
\hline
\end{tabular}




\section{Gaps and Future Directions}

This section will highlight some of the gaps found in the literature review and attempt to point out some possible future questions that can be further explored. It can be noticed that the number of studies that explored the effect of the teachers' corrective feedback practices is still small. Only nine studies explored the teachers' practices, and nineteen studies compared the effect of different EWCF types and their effects. More research can be conducted to confirm the effectiveness of EWCF further and investigate the different factors that may play a role in the process. The following section will give an elaboration on each of the studies' possible gaps and future directions (Analytical and Experimental) individually.

\section{Analytical studies}

1- Few studies examined the effectiveness of EWCF in its natural setting. Therefore, more studies are still required. Four studies analyzed the EWCF on students' written assignments, with each study examining a relatively small group of participants. There is an exception of one study (Ene \& Upton, 2018) that examined a relatively large group of students $(n=64)$. However, there is a need to conduct more investigations on larger students before any generalizations can be made.

2-There is a need to include a variety of data collection techniques in future research. Most of the studies $(n=7)$ used the teachers' and students' output as the primary data source for their investigations. Only two of the studies included stimulated recall as a method of gathering data. Breffni O'Rourke (2012) pointed to this gap and referred to different data collection methods that may give a more comprehensive view of the effectiveness of EWCF. These methods include: 1Timestamped output logs, 2- Retrospective user report, 3- Keystroke logs, 4- Screen captured video, 5- Video recording of physical environment subjects (Orourke, 2012).

3- There is a need to review the types of Electronic Corrective Feedback and the teachers' practices when delivered to students with different language proficiency levels. This need aligns with other studies that called for specific attention to students' effect at different levels in L2 and its effectiveness on the EWCF given to them (Bitchener, 2016; Su \& Tian, 2016).

4- There is a need to investigate the effect of different tools to provide EWCF. The current analytical studies reviewed in this paper investigated a limited number of tools, either synchronously or asynchronously (Namely, LMS, MS WORD, Microsoft Windows Messenger, and Skype). However, none of the studies investigated the other available tools such as Ginger, Markin4 and other tools. Thus further exploration could be done to determine the effect of these tools on the teacher's practices in providing ECT and their effect on the students.

\section{Experimental Studies}

1- There is a need to focus on investigating the role of EWCF in future experimental studies. The need is evident from analyzing the feedback practices conducted by ESL Writing teachers in natural settings. It was noticed that most of the feedback delivered to the students tends to be direct and explicit. However, there are only four studies that compared direct corrective feedback against other types of feedback. That is why more research could be conducted to analyze the effect of direct feedback thoroughly.

2- Most of the experimental studies reviewed in this paper focused on two primary teacher EWCF types: recasts and metalinguistic explanations. On the other hand, fewer studies compared them with other types of feedback, such as prompts and direct feedback. There should be more 
focus on examining the effectiveness of the other feedback methods. The focus includes direct feedback that showed promising results and indirect feedback that has been rarely investigated.

3- There is still a need to explore different Feedback types that have not been investigated previously. Based on Lyster and Ranta's (1997) classification of feedback moves, there are seven feedback types (Explicit, metalinguistic explanation, Elicitation, Repetitions, Recasts, Translation, and clarification requests). Some of these types are still absent from the ECF research. Absent research includes using translations and elicitations. Exploring these methods would contribute to our understanding of their nature and effectiveness in EWCF practices.

4- Providing EWCF methods in the reviewed studies here tends to compare two or three types of feedback separately. However, there are no studies in this body of research that investigated the provision of multiple types (For example, giving the same group of students different types of ECF on their assignment) to study their effect and the best combination of feedback and their relation

5- Most of the experimental studies reviewed used the students' output as the primary source of data to examine the effectiveness of EWCF. However, other sources of data could be used in the analysis of the effectiveness of EWCF. These sources include the use of Eye-tracking and electroencephalogram devices. It also includes using keyboard stroke logs and video recording of the participants" practices during the ECF sessions (O'rourke, 2012; O'Rourke, 2008).

\section{Conclusion}

Giving corrective feedback to the students' written errors is an issue that has attracted and continues attention in second language writing studies. With the advancement of communication technologies, new possibilities became available in the field, including applying these possibilities to improve the students' grammatical errors. This paper attempted to survey the existing literature regarding the use of technology in providing teacher corrective feedback. The primary purpose was to identify the current trends and possible gaps in future exploration. The results indicated that there is still a shortage of ECF studies with a strong focus on specific feedback types. New methods of collecting data could be implemented, such as eye-tracking and electroencephalogram devices.

\section{About the authors}

Omar Abdullah Altamimi is a PhD candidate, center for Instructional Technology and Multimedia. Universiti Sains Malaysia. Penang. Malaysia. His interest includes using affordable and accessible instructional technologies to help underprivileged ESL/ EFL students improving their writing skills. http://orcid.org/0000-0003-4374-8791

Professor Mona Masood received her PhD in Instructional Systems Technology from Indiana University, Bloomington and is currently the Deputy Director at the Centre for Instructional Technology and Multimedia, Universiti Sains Malaysia. Her research interest lies in Eye tracking, Human Computer Interaction, and Virtual Reality. http://orcid.org/0000-0002-3200-8918

\section{References}

Akbar, F. S. (2017). Corrective feedback in written synchronous and asynchronous computermediated communication. Working Papers in Applied Linguistics \& TESOL, 17(2), 9-27. 
Arab World English Journal (AWEJ) Volume 12. Number 3. September 2021

Altamimi \& Masood

Al-saleh, N. A. (2018). Corrective feedback. Arab World English Journal (AWEJ), 2 (4), 1-121.

Alipanahi, F., \& Mahmoodi, R. (2015). Corrective feedback via e-mail on the correct use of past tense among iranian EFL learners. South African Journal of Education, 35(4), 1-19.

Bataineh, A. M. (2014). The effect of text chat assisted with word processors on saudi English major students' writing accuracy and productivity of authentic texts. International Journal of Emerging Technologies in Learning, 9(9), 32-40. https://doi.org/10.3991/ijet.v9i9.4119

Bitchener, J. (2016). To what extent has the published written CF research aided our understanding of its potential for L2 development? International Journal of Applied Linguistics and English Literature, 167(2), 111-131. https://doi.org/10.1075/itl.167.2.01bit

Orourke, B. (2012). Using eye-tracking to investigate gaze behaviour in synchronous computermediated communication for language learning Individual processes in SCMC. In Researching online foreign language interaction and exchange: Theories, methods and challenges (pp. 11-44).

DeBell, M. (2003). Computer and Internet use by children and adolescents in 2001. National Center for Education Statistics, US Department of Education.

Ene, E. \& Upton, T (2014). Learner uptake of teacher electronic feedback in ESL composition. System, 46, 80-95. https://doi.org/10.1016/j.system.2014.07.011

Ene, E., \& Upton, T. (2018). Synchronous and asynchronous teacher electronic feedback and learner uptake in ESL composition. Journal of Second Language Writing, 41(2), 1-13. https://doi.org/10.1016/j.jslw.2018.05.005

Esfandiari, R., \& Meihami, H. (2017). Impact of direct corrective feedback (dcf) through electronic portfolio (ep) platform on the components of iranian EFL learners' writing across levels of language proficiency. Journal of Teaching Language Skills (JTLS), 4O(3), 1-17. https://doi.org/10.22099/jtls.2017.24570.2204

Guénette, D., \& Lyster, R. (2013a). Written corrective feedback and its challenges for preservice ESL teachers. Canadian Modern Language Review, 46, 80-95. https://doi.org/10.3138/cmlr.1346

Guénette, D., \& Lyster, R. (2013b). Written corrective feedback and its challenges for preservice ESL teachers. Canadian Modern Language Review, 69(2), 129-153. https://doi.org/10.3138/cmlr.1346

He, H. (2016). A survey of EFL college learners' perceptions of an online writing program. International Journal of Emerging Technologies in Learning, 11(4), 11-15. https://doi.org/10.3991/ijet.v11i04.5459

Hosseini, S. B. (2012). Asynchronous computer-mediated corrective feedback and the correct use of prepositions : Is It Really Effective? Turkish Online Journal of Distance Education, 13(4), 95-111.

Hosseini, S. (2013). Impact of asynchronous computer-mediated corrective feedback on increasing iranian EFL learners' correct use of present tenses. International Journal on New Trends in Education \& Their Implications (IJONTE), 4(1), 138-153.

Hyland, F. (2010). Future Directions in Feedback on Second Language Writing: Overview and Research Agenda. International Journal of English Studies, 10(2), 171-182.

Hyland, K., \& Hyland, F. (2006). Feedback on second language students' writing. Language Teaching, 39(2), 83-101. https://doi.org/10.1017/S0261444806003399

Kim, H. Y. (2014). Revisiting synchronous computer-mediated communication: learner perception and the meaning of corrective feedback. English Language Teaching, 7(9), 6473. https://doi.org/10.5539/elt.v7n9p64 
Altamimi \& Masood

Kim, M., \& Cho, Y. W. (2016). The effects of metalinguistic and exemplar-based written corrective feedback on English verb complementation accuracy in multimedia-based EFL writing instruction. Multimedia-Assisted Language Learning, 19(2), 34-60. Retrieved from http://10.0.61.86/mall.2016.19.2.34

Lee, J., Vahabi, F., \& Bikowski, D. (2018). Second language teachers' written response practices: an in-house inquiry and response. Journal of Response to Writing, 4(1), 34-69.

Loewen, S., \& Erlam, R. (2006). Corrective feedback in the chatroom: An experimental study. Computer Assisted Language Learning. https://doi.org/10.1080/09588220600803311

Lv, X. (2018). A study on the application of automatic scoring and feedback system in college English writing. International Journal of Emerging Technologies in Learning, 13(3), 188196. https://doi.org/10.3991/ijet.v13i03.8386

Lyster, R., \& Ranta, L. (1997). Corrective feedback and learner uptake negotiation of form in communicative classrooms. Studies in Second Language Acquisition, 19(1), 37-66. https://doi.org/10.1017/S0272263197001034

Maas, C. (2017). Perceptions of multimodal learner-driven feedback in EAP. Writing \& Pedagogy, 9(3), 487-516. https://doi.org/10.1558/wap.33292

Martin-Beltrán, M., \& Chen, P. (2013). From monologue to dialogue: A case study on mediated feedback in a transnational asynchronous online writing tutorial. Academic Exchange Quarterly, 17(1), 145-150.

Mousavi, F., \& Mahshanian, A. (2016). The effect of corrective feedback strategies via e-mail on writing accuracy improvement: A case of iranian EFL learners. Academic Journal of Interdisciplinary Studies, 5(3), 149-158. https://doi.org/10.5901/ajis.2016.v5n3p149

O'Rourke, B. (2008). The other C in CMC: What alternative data sources can tell us about textbased synchronous computer-mediated communication and language learning. Computer Assisted Language Learning, 21(3), 227-251.

Pellettieri, J. (2000). Negotiation in cyberspace: The role of chatting in the development of grammatical competence. Network-Based Language Teaching: Concepts and Practice, 59, 86.

Rassaei, E. (2019). Computer-mediated text-based and audio-based corrective feedback, perceptual style and L2 development. System, 82, 97-110. https://doi.org/10.1016/j.system.2019.03.004

Rassaei, Ehsan. (2019). Computer-mediated text-based and audio-based corrective feedback, perceptual style and L2 development. System, 82(1), 97-110. https://doi.org/10.1016/j.system.2019.03.004

Razagifard, Parisa Razzaghifard, V. (2011). Corrective feedback in a computer-mediated communicative context and the development of second language grammar. Teaching English with Technology, 11(2), 1-17.

Razagifard, P., \& Rahimpour, M. (2019). The effect of computer-mediated corrective feedback on the development of second language learners ' grammar. Instructional Technology \& Distance Learning, 7(5), 1-17.

Ribeiro, A. (2018). Negotiation of meaning and corrective feedback in face-to-face and computer-mediated interactions. Electronic International Journal of Education, Arts, and Science, 4(9), 42-62.

Saadi, Z. K., \& Saadat, M. (2015). EFL learners' writing accuracy: Effects of direct and metalinguistic electronic feedback. Theory \& Practice in Language Studies, 5(10), 2053 2063. Retrieved from http://10.0.68.99/tpls.0510.11 
Samani, E., \& Noordin, N. (2013). A comparative study of the effect of recasts and prompts in synchronous computer-mediated communication (SCMC) on students' achievement in grammar. Middle East Journal of Scientific Research, 15(1), 46-54. https://doi.org/10.5829/idosi.mejsr.2013.15.1.2274

Sauro, S. (2007). A comparative study of recasts and metalinguistic feedback through computer $\mathrm{m}$ ediated communication on the development of 12 know ledge and production accuracy. $\mathrm{PhD}$ dissertation. University of Pennsylvania.

Sauro, S. (2009). Computer-mediated corrective feedback and the development of 12 grammar. Language Learning \& Technology, 13(1), 96-120. Retrieved from http://llt.msu.edu/default.html

Shintani, N, \& Aubrey, S. (2016). The effectiveness of synchronous and asynchronous written corrective feedback on grammatical accuracy in a computer-mediated environment. The Modern Language Journal, 100(1), 296-319. https://doi.org/10.1111/modl.12317

Shintani, N. (2015). The effects of computer-mediated synchronous and asynchronous direct corrective feedback on writing : a case study. Computer Assisted Language Learning, 29(3), 1-22. https://doi.org/10.1080/09588221.2014.993400

Shintani, N., \& Ellis, R. (2013). The comparative effect of direct written corrective feedback and metalinguistic explanation on learners' explicit and implicit knowledge of the English indefinite article. Journal of Second Language Writing, 22(3), 286-306. https://doi.org/10.1016/j.jslw.2013.03.011

Smith, B. (2010). Employing eye-tracking technology in researching the effectiveness of recasts in CMC. In Directions and prospects for educational linguistics (pp. 79-97). https://doi.org/10.1007/978-90-481-9136-9_6

Smith, B. (2012). Eye-tracking as a measure of noticing: A study of explicit recasts in SCMC. Language Learning and Technology, 16(3), 53-81.

Su, T., \& Tian, J. (2016). Research on corrective feedback in ESL / EFL classrooms. Theory \& Practice in Language Studies, 6(2), 439-444.

Warschauer, M. (1996). comparing face-to-face and electronic discussion in the second language classroom. CALICO Journal, 13(2), 7-26.

Xu, Z., Banerjee, M., Ramirez, G., Zhu, G., \& Wijekumar, K. (2019). The effectiveness of educational technology applications on adult English language learners' writing quality: a meta-analysis. Computer Assisted Language Learning, 32(1-2), 132-162. 
Arab World English Journal (AWEJ) Volume 12. Number 3. September 2021

Teacher Electronic Written Corrective Feedback

Altamimi \& Masood

Appendix A: Summary of Analytical Studies

\begin{tabular}{|c|c|c|c|c|}
\hline Author & Level & Mode & Tool & Type of Feedback \\
\hline $\begin{array}{c}\text { (Martin- } \\
\text { Beltrán \& } \\
\text { Chen, } \\
\text { 2013) }\end{array}$ & $\begin{array}{c}\text { Students are enrolled in } \\
\text { English Academic Writing } \\
\text { course }\end{array}$ & Asynchronous & $\begin{array}{l}\text { Discussion forum in } \\
\text { online LMS }\end{array}$ & $\begin{array}{c}\text { Asking questions, 2- } \\
\text { Metalinguistic, 3- Giving } \\
\text { examples }\end{array}$ \\
\hline $\begin{array}{l}\text { (Guénette } \\
\text { \& Lyster, } \\
\text { 2013b) }\end{array}$ & Intermediate & Asynchronous & E-mail & Direct \\
\hline $\begin{array}{l}\text { (Ene \& } \\
\text { Upton, } \\
\text { 2014) }\end{array}$ & First-Year College & Asynchronous & $\begin{array}{l}\text { MS Word in the Learning } \\
\text { Management System }\end{array}$ & Direct \\
\hline $\begin{array}{l}\text { (Lee et } \\
\text { al., 2018) }\end{array}$ & $\begin{array}{l}\text { A score below } 24 \text { in the } \\
\text { TOEFL IBT Writing section }\end{array}$ & Asynchronous & Not described & Direct \\
\hline $\begin{array}{l}\text { (H. Y. } \\
\text { Kim, } \\
2014)\end{array}$ & intermediate & Synchronous & $\begin{array}{l}\text { Microsoft Window } \\
\text { Messenger }\end{array}$ & Implicit \\
\hline $\begin{array}{l}\text { (Ribeiro, } \\
\text { 2018) }\end{array}$ & Intermediate & Synchronous & Skype text-messaging & $\begin{array}{l}\text { 1- Direct, } 2 \text { Clarification } \\
\text { Request, 3- Metalinguistic, } \\
\text { 4- Elicitation, 5- Repetition }\end{array}$ \\
\hline $\begin{array}{l}\text { (Natsuko } \\
\text { Shintani, } \\
\text { 2015) }\end{array}$ & Intermediate & $\begin{array}{l}\text { Synchronous } \\
\text { and } \\
\text { Asynchronous }\end{array}$ & Google Docs & Direct \\
\hline $\begin{array}{l}\text { (Akbar, } \\
\text { 2017) }\end{array}$ & High Intermediate & $\begin{array}{l}\text { Synchronous } \\
\text { and } \\
\text { Asynchronous }\end{array}$ & $\begin{array}{c}\text { Google Docs and Google } \\
\text { Talk }\end{array}$ & $\begin{array}{c}\text { Clarification requests, } 2- \\
\text { Recast }\end{array}$ \\
\hline $\begin{array}{l}\text { (Ene \& } \\
\text { Upton, } \\
\text { 2018) }\end{array}$ & EAP Level & $\begin{array}{l}\text { Synchronous } \\
\text { and } \\
\text { Asynchronous }\end{array}$ & LMS and MS Word & Mixed \\
\hline
\end{tabular}

Appendix B: Summary of Experimental Studies

\begin{tabular}{|l|l|l|l|l|l|l|}
\hline Author & Sample & Level & $\begin{array}{l}\text { Data Collection } \\
\text { Method }\end{array}$ & Mode & Tool & $\begin{array}{l}\text { Type of } \\
\text { Feedback }\end{array}$ \\
\hline $\begin{array}{l}\text { (Loewe } \\
\text { n \& } \\
\text { Erlam, } \\
\text { 2006) }\end{array}$ & $\begin{array}{l}31 \text { ESL } \\
\text { students }\end{array}$ & $\begin{array}{l}\text { Eleme } \\
\text { ntary }\end{array}$ & $\begin{array}{l}\text { Pretest, Treatment, } \\
\text { Posttest, Delayed } \\
\text { Posttest }\end{array}$ & $\begin{array}{l}\text { Synchronou } \\
\mathrm{s}\end{array}$ & $\begin{array}{l}\text { Chatroom } \\
\text { program in a } \\
\text { computer } \\
\text { center }\end{array}$ & $\begin{array}{l}\text { Recast and } \\
\text { Metalinguistic }\end{array}$ \\
\hline $\begin{array}{l}\text { (Sauro, } \\
\text { 2007) }\end{array}$ & 23 & $\begin{array}{l}\text { high } \\
\text { interm } \\
\text { ediate } \\
\text { to } \\
\text { Advan } \\
\text { ced }\end{array}$ & $\begin{array}{l}\text { Pretest, Treatment, } \\
\text { Posttest, Delayed } \\
\text { Posttest }\end{array}$ & $\begin{array}{l}\text { Asynchrono } \\
\text { us }\end{array}$ & Blackboard & $\begin{array}{l}\text { Recast and } \\
\text { Metalinguistic }\end{array}$ \\
\hline
\end{tabular}


Arab World English Journal (AWEJ) Volume 12. Number 3. September 2021

Teacher Electronic Written Corrective Feedback

Altamimi \& Masood

\begin{tabular}{|c|c|c|c|c|c|c|}
\hline $\begin{array}{l}\text { (Sauro, } \\
\text { 2009) }\end{array}$ & $\begin{array}{l}23 \text { ESL } \\
\text { speakers } \\
\text { and } 23 \\
\text { Native } \\
\text { speakers }\end{array}$ & $\begin{array}{l}\text { interm } \\
\text { ediate } \\
\text { to } \\
\text { advan } \\
\text { ced }\end{array}$ & $\begin{array}{l}\text { Pretest, Treatment, } \\
\text { Posttest, Delayed } \\
\text { Posttest }\end{array}$ & $\begin{array}{l}\text { Synchronou } \\
\text { S }\end{array}$ & Text Chat & $\begin{array}{l}\text { Recast and } \\
\text { Metalinguistic }\end{array}$ \\
\hline $\begin{array}{l}\text { (Razagi } \\
\text { fard \& } \\
\text { Rahimp } \\
\text { our, } \\
\text { 2019) }\end{array}$ & 30 students & $\begin{array}{l}\text { Begin } \\
\text { ner }\end{array}$ & $\begin{array}{l}\text { Pretest, Treatment, } \\
\text { Posttest }\end{array}$ & $\begin{array}{l}\text { Synchronou } \\
\text { S }\end{array}$ & $\begin{array}{l}\text { Yahoo! Instant } \\
\text { Messenger }\end{array}$ & $\begin{array}{l}\text { Recast and } \\
\text { Metalinguistic }\end{array}$ \\
\hline $\begin{array}{l}\text { (Smith, } \\
\text { 2010) }\end{array}$ & $8 \mathrm{ESL}$ & $\begin{array}{l}\text { TOEF } \\
\mathrm{L} \\
\text { betwe } \\
\text { en } 497 \\
\text { to } 617\end{array}$ & $\begin{array}{l}\text { Treatment and } \\
\text { Posttest through eye } \\
\text { tracker }\end{array}$ & $\begin{array}{l}\text { Synchronou } \\
\text { S }\end{array}$ & Text Chat & Recast only \\
\hline $\begin{array}{l}\text { (Razagi } \\
\text { fard, } \\
\text { Razzag } \\
\text { hifard, } \\
\text { 2011) }\end{array}$ & $\begin{array}{l}45 \mathrm{ESL} \\
\text { students }\end{array}$ & $\begin{array}{l}\text { Low } \\
\text { Interm } \\
\text { ediate }\end{array}$ & $\begin{array}{l}\text { Pretest, Treatment, } \\
\text { Posttest }\end{array}$ & $\begin{array}{l}\text { Synchronou } \\
\text { S }\end{array}$ & $\begin{array}{l}\text { Yahoo! Instant } \\
\text { Messenger }\end{array}$ & $\begin{array}{l}\text { Recast and } \\
\text { Metalinguistic }\end{array}$ \\
\hline $\begin{array}{l}\text { (HOsse } \\
\text { ini, } \\
\text { 2012) }\end{array}$ & $\begin{array}{l}45 \text { Iranian } \\
\text { elementary } \\
\text { students }\end{array}$ & $\begin{array}{l}\text { Eleme } \\
\text { ntary }\end{array}$ & $\begin{array}{l}\text { Pretest, Treatment, } \\
\text { Posttest }\end{array}$ & $\begin{array}{l}\text { Asynchrono } \\
\text { us }\end{array}$ & E-mail & $\begin{array}{l}\text { Direct and } \\
\text { Recast }\end{array}$ \\
\hline $\begin{array}{l}\text { (Smith, } \\
\text { 2012) }\end{array}$ & $18 \mathrm{ESL}$ & $\begin{array}{l}\text { FYC } \\
\text { studen } \\
\text { ts }\end{array}$ & $\begin{array}{l}\text { Pre-test, treatment, } \\
\text { post-test, and } \\
\text { delayed post-test. } \\
\text { And Eye tracker }\end{array}$ & $\begin{array}{l}\text { Synchronou } \\
\mathrm{S}\end{array}$ & $\begin{array}{l}\text { Chat program } \\
\text { called PSI }\end{array}$ & Recast only \\
\hline $\begin{array}{l}\text { (Hossei } \\
\text { ni, } \\
\text { 2013) }\end{array}$ & $\begin{array}{l}45 \text { Iranian } \\
\text { elementary } \\
\text { students }\end{array}$ & $\begin{array}{l}\text { Eleme } \\
\text { ntary }\end{array}$ & $\begin{array}{l}\text { Pretest, Treatment, } \\
\text { Posttest }\end{array}$ & $\begin{array}{l}\text { Asynchrono } \\
\text { us }\end{array}$ & Email & $\begin{array}{l}\text { Direct and } \\
\text { Recast }\end{array}$ \\
\hline $\begin{array}{l}\text { (Saman } \\
\text { i \& } \\
\text { Noordi } \\
\text { n, } \\
\text { 2013) }\end{array}$ & $\begin{array}{l}30 \text { Iranian } \\
\text { students }\end{array}$ & $\begin{array}{l}\text { interm } \\
\text { ediate }\end{array}$ & $\begin{array}{l}\text { Pretest, Treatment, } \\
\text { Posttest }\end{array}$ & $\begin{array}{l}\text { Asynchrono } \\
\text { us }\end{array}$ & $\begin{array}{l}\text { Yahoo! Instant } \\
\text { Messenger }\end{array}$ & $\begin{array}{l}\text { Recast and } \\
\text { Prompt }\end{array}$ \\
\hline $\begin{array}{l}\text { (Natsuk } \\
\text { o } \\
\text { Shintan } \\
\text { i \& } \\
\text { Ellis, } \\
\text { 2013) }\end{array}$ & 49 & $\begin{array}{l}\text { Low } \\
\text { interm } \\
\text { ediate }\end{array}$ & $\begin{array}{l}\text { Pre-test, treatment, } \\
\text { post-test, and } \\
\text { delayed post-test, } \\
\text { eye tracker and } \\
\text { Stimulated recall }\end{array}$ & $\begin{array}{l}\text { Asynchrono } \\
\text { us }\end{array}$ & Not described & $\begin{array}{l}\text { Direct and } \\
\text { Metalinguistic }\end{array}$ \\
\hline $\begin{array}{l}\text { (Alipan } \\
\text { ahi \& } \\
\text { Mahmo } \\
\text { odi, } \\
\text { 2015) } \\
\end{array}$ & $\begin{array}{l}60 \text { Iranian } \\
\text { Esl students }\end{array}$ & $\begin{array}{l}\text { Pre- } \\
\text { Interm } \\
\text { ediate }\end{array}$ & $\begin{array}{l}\text { Pretest, Treatment, } \\
\text { Posttest, Delayed } \\
\text { Posttest }\end{array}$ & $\begin{array}{l}\text { Asynchrono } \\
\text { us }\end{array}$ & Email & $\begin{array}{l}\text { Direct and } \\
\text { Recast }\end{array}$ \\
\hline $\begin{array}{l}\text { (Saadi } \\
\& \\
\text { Saadat, } \\
\text { 2015) }\end{array}$ & $\begin{array}{l}29 \text { Iranian } \\
\text { ESL } \\
\text { students }\end{array}$ & $\begin{array}{l}\text { Upper } \\
\text { - } \\
\text { interm } \\
\text { ediate }\end{array}$ & $\begin{array}{l}\text { Pretest, Treatment, } \\
\text { Posttest, 2- The } \\
\text { CALL Attitude } \\
\text { Questionnaire }\end{array}$ & $\begin{array}{l}\text { Asynchrono } \\
\text { us }\end{array}$ & $\begin{array}{l}\text { Ginger and } \\
\text { Markin4 }\end{array}$ & $\begin{array}{l}\text { Direct and } \\
\text { Metalinguistic }\end{array}$ \\
\hline $\begin{array}{l}\text { Mousa } \\
\text { vi \& } \\
\text { Mahsha } \\
\text { nian, }\end{array}$ & $\begin{array}{l}\text { 84 Iranian } \\
\text { EFL } \\
\text { students }\end{array}$ & $\begin{array}{l}\text { High } \\
\text { Interm } \\
\text { ediate }\end{array}$ & $\begin{array}{l}\text { Pretest, Treatment, } \\
\text { Posttest, Delayed } \\
\text { Posttest }\end{array}$ & $\begin{array}{l}\text { Asynchrono } \\
\text { us }\end{array}$ & $\begin{array}{l}\text { E-mail and } \\
\text { MS Word }\end{array}$ & Direct, indirect, \\
\hline
\end{tabular}


Arab World English Journal (AWEJ) Volume 12. Number 3. September 2021

\begin{tabular}{|c|c|c|c|c|c|c|}
\hline 2016) & & & & & & \\
\hline $\begin{array}{l}\text { M. } \\
\text { Kim \& } \\
\text { Cho, } \\
2016) \\
\end{array}$ & $\begin{array}{l}52 \text { Koran } \\
\text { English } \\
\text { learners }\end{array}$ & $\begin{array}{l}\text { beginn } \\
\text { er to } \\
\text { advan } \\
\text { ced }\end{array}$ & $\begin{array}{l}\text { Pretest, Treatment, } \\
\text { Posttest }\end{array}$ & $\begin{array}{l}\text { Asynchrono } \\
\text { us }\end{array}$ & $\begin{array}{l}\text { PowerPoint } \\
\text { and Movie }\end{array}$ & $\begin{array}{l}\text { Metalinguistic } \\
\text { and exemplar }\end{array}$ \\
\hline $\begin{array}{l}\text { Shintan } \\
\text { i \& } \\
\text { Aubrey } \\
\text {, 2016) } \\
\end{array}$ & $\begin{array}{l}68 \text { ESL } \\
\text { students } \\
\text { from Japan }\end{array}$ & $\begin{array}{l}\text { Interm } \\
\text { ediate }\end{array}$ & $\begin{array}{l}\text { Pretest, Treatment, } \\
\text { Posttest, Delayed } \\
\text { Posttest }\end{array}$ & $\begin{array}{l}\text { Synchronou } \\
\text { s and } \\
\text { Asynchrono } \\
\text { us }\end{array}$ & Google Docs & Direct \\
\hline $\begin{array}{l}\text { Esfand } \\
\text { iari \& } \\
\text { Meiha } \\
\text { mi, } \\
\text { 2017) }\end{array}$ & $\begin{array}{l}\text { (60) Iranian } \\
\text { EFL } \\
\text { learners }\end{array}$ & $\begin{array}{l}\text { Begin } \\
\text { ner- } \\
\text { Interm } \\
\text { ediate- } \\
\text { Advan } \\
\text { ced }\end{array}$ & $\begin{array}{l}\text { Pretest, Treatment, } \\
\text { Posttest }\end{array}$ & $\begin{array}{l}\text { Synchronou } \\
\text { s and } \\
\text { Asynchrono } \\
\text { us }\end{array}$ & $\begin{array}{l}\text { Electronic } \\
\text { Portfolio } \\
\text { called } \\
\text { DOKEOS }\end{array}$ & Direct \\
\hline $\begin{array}{l}\text { (Al- } \\
\text { saleh, } \\
2018)\end{array}$ & $\begin{array}{l}24 \mathrm{EFL} \\
\text { female } \\
\text { students }\end{array}$ & $\begin{array}{l}\text { They } \\
\text { are } \\
\text { studen } \\
\text { ts in } \\
\text { Bachel } \\
\text { or } \\
\text { degree } \\
\text { in } \\
\text { Englis } \\
\text { h }\end{array}$ & $\begin{array}{l}\text { Pre-test, Treatment, } \\
\text { Posttest,--- } \\
\text { Questionnaire }\end{array}$ & $\begin{array}{l}\text { Asynchrono } \\
\text { us }\end{array}$ & $\begin{array}{l}\text { LMS called } \\
\text { Showbie }\end{array}$ & $\begin{array}{l}\text { Direct, indirect, } \\
\text { and } \\
\text { metalinguistic }\end{array}$ \\
\hline $\begin{array}{l}\text { (Ehsan } \\
\text { Rassaei } \\
\text {, 2019) }\end{array}$ & $\begin{array}{l}89 \text { Iranian } \\
\text { students }\end{array}$ & $\begin{array}{l}\text { Interm } \\
\text { ediate }\end{array}$ & $\begin{array}{l}\text { Pretest, Treatment, } \\
\text { Posttest }\end{array}$ & $\begin{array}{l}\text { Asynchrono } \\
\text { us }\end{array}$ & $\begin{array}{l}\text { The } \\
\text { Annotation } \\
\text { tool and the } \\
\text { audio tool in } \\
\text { PDF }\end{array}$ & Direct \\
\hline
\end{tabular}

